\title{
Grand challenges in marine ecosystems ecology
}

\author{
Angel Borja * \\ AZTI-Tecnalia, Marine Research Division, Pasaia, Spain \\ *Correspondence: aborja@azti.es \\ Edited by: \\ Alberto Basset, University of Salento, Italy
}

Keywords: biodiversity, functionality, human pressures, global change, ecosystems health, ecosystem services, conservation and protection, ecosystem-based management

\section{INTRODUCTION}

The study of marine ecosystems has become a hot research topic in recent times. In fact, the number of manuscripts including the words "marine ecosystems" published since 1970 has immensely increased reaching between 1100 and 1500 articles per year in the past five years (Figure 1). Based on the keywords used in these manuscripts, the most frequent topics can be grouped into: (i) marine ecosystems $(28.8 \%$ of the papers); (ii) biodiversity (26.6\%), used as keyword at any level of organization, such as bacteria, phytoplankton, zooplankton, benthos, fishes, mammals, seabirds, etc.; (iii) functionality $(10.7 \%)$, including aspects such as ecosystem function, biomass, foodwebs, primary and secondary production, etc.; (iv) environmental research (9.7\%), including pollution, environmental monitoring, human pressures, impacts, etc.; (v) structural parameters $(6.6 \%)$ such as abundance, richness, diversity; (vi) climate change (3.4\%); (vii) ecology (3.4\%); (viii) systems management (3.2\%); (ix) genetic and genomic issues $(1.6 \%) ;(\mathrm{x})$ protection (1\%); (xi) ecosystem modeling (0.9\%); and (xii) others $(4.5 \%)$.

Taking into account the large number of papers published in recent years, several grand challenges can be identified for future research within the field of marine ecosystem ecology and as outlined below.

\section{GRAND CHALLENGE 1:}

\section{UNDERSTANDING THE ROLE OF} BIODIVERSITY IN MAINTAINING ECOSYSTEMS FUNCTIONALITY

Currently, the global species extinction rate far exceeds that of speciation, this difference being the primary driver for change in global biodiversity (Hooper et al., 2012). The rate of biodiversity loss is one of the 10 planetary boundaries within which humanity can operate safely that has already been exceeded (Rockström et al., 2009). The effects of this global decline in biodiversity provide evidence of its importance in sustaining ecosystem functioning and services and preventing ecosystems

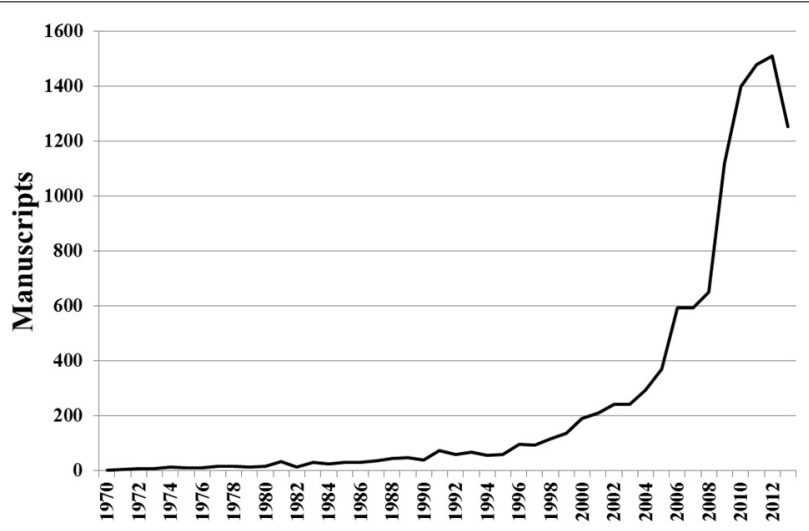

FIGURE 1 | Number of manuscripts published under the term: "marine ecosystem," appearing in the abstract, title or keywords, since 1970, within the Science Citation Index journal (consulted in SCOPUS, on 17th November 2013).

from tipping into undesired states (Folke et al., 2004).

Historically, researchers have investigated ecosystems focusing on individual or few components of biodiversity, i.e., microbes, phytoplankton, zooplankton, macroalgae, macroinvertebrates, fishes, mammals, seabirds, etc., trying to understand individual species' roles. However, it is now recognized that understanding the entire ecosystem requires the study of all biodiversity components, from the genetic structure of populations, to species, habitats and ecosystem integrity, including food-webs and complex bio-physical interrelationships within the system.

Thompson et al. (2012) emphasize that food-web ecology will act as an underlying conceptual and analytical framework for studying biodiversity and ecosystem function, if the following challenges are addressed: (i) relating food-web structure to ecosystem function; (ii) combining food-web and ecosystem modeling; (iii) transitioning from individual traits to ecosystem function; (iv) incorporating space and time in studies; and (v) understanding the effects of biodiversity loss on ecosystem function.

The study of the ecological function of biodiversity is very recent; yet, it has been recognized to have fundamental implications for predicting the consequences of biodiversity loss (Benedetti-Cecchi, 2005). Species in an ecosystem can be functionally equivalent, meaning that they play the same role. As such, these functionally equivalent species can be grouped together as functional types (i.e., guilds, trophic groups, structural groups, ecological groups, traits). Other key attributes of biodiversity organization, such as the density mass-relationship between abundance and body size, have become a major 
research area. These attributes relate to food webs, determined by the trophic position, predator-prey relationships, and energy balance. Theoretically, a higher number of functional group types will provide higher functional biodiversity organization to the system, and thus, contribute to more stable and resilient ecosystems (Tomimatsu et al., 2013).

Despite the importance of this question, the relationship between diversity and stability is still being resolved. As with many biodiversity-related topics, there are different ways of expressing stability. One way is to define it as the ability of a system to return to its original state after being disturbed (i.e., resilience), so how quickly it can return and how large a disturbance it can return from are key variables (Elliott et al., 2007). Another definition is how resistant to change the system is in the first place. No matter which definition is used, there are definite trends that appear.

Finally, a major issue in maintaining the functionality of ecosystems comes from invasive species, which can dramatically disturb stable systems thereby impacting ecosystem services (Sorte et al., 2010; Vilà et al., 2010). Methods to detect and control this biological pollution are therefore needed (Olenin et al., 2011).

\section{GRAND CHALLENGE 2: UNDERSTANDING RELATIONSHIPS BETWEEN HUMAN PRESSURES AND ECOSYSTEMS}

Global biodiversity is threatened by human activities which are increasingly impacting marine ecosystems (Halpern et al., 2008). These impacts are usually cumulative and can lead to degrading habitats and ecosystem functionality (Ban et al., 2010). In some seas, such as the Mediterranean and Black Sea, less than $1 \%$ of the surface is considered unaffected by human disturbance with most of the surface affected by cumulative impacts (Micheli et al., 2013). There is evidence that the likelihood of regime shifts may increase as a result of reduced ecosystem resilience through a decrease in diversity, functional groups of species or trophic levels, thereby impacting ecosystems (with waste, pollutants and climate change) and altering the magnitude, frequency, and duration of disturbance regimes (Folke et al., 2004).
Current socio-ecological theories consider humans as part of the marine ecosystem (Livingston et al., 2011). Hence, understanding the relationships between human activities and their various impacts on marine ecosystems represents another grand challenge to be discussed within the specialty section of Marine Ecosystem Ecology.

\section{GRAND CHALLENGE 3: UNDERSTANDING THE IMPACT OF GLOBAL CHANGE ON MARINE ECOSYSTEMS}

Sea waters are getting warmer, sea-level rise is accelerating and the oceans are becoming increasingly acidic (Stocker et al., 2013). From a database of 1735 marine biological responses to global change, Poloczanska et al. (2013) determined that $81-83 \%$ of all observations for distribution, phenology, community composition, abundance, demography and calcification across taxa and ocean basins were consistent with the expected impacts of climate change on marine life (Richardson et al., 2012).

As there is an insufficient understanding of the capacity for marine organisms to adapt to rapid climate change, Munday et al. (2013) emphasize that an evolutionary perspective is crucial to understanding climate change impacts on our seas and to examine the approaches that may be useful for addressing this challenge.

We need also a deeper understanding of the climate change impact on body size and the cascading implications on ecosystem functioning, considering the recent attempt of applying metabolic theory on modeling the biosphere. Hence, organisms often have smaller body sizes under warmer climates, and body size is a major determinant of functionality of the ecosystems, as commented above. Therefore, by altering body sizes in whole communities, current warming can potentially disrupt ecosystem function and services (Edeline et al., 2013).

In addition, our understanding of the linkages between climate change and anthropogenic disturbances needs to be improved. Borja et al. (2013b), investigating the combined effects of human pressures (i.e., exploitation and waste discharges) and environmental variables (i.e., light, waves, temperature) in macroalgae over a long-term series, demonstrated that in impacted areas macroalgae are more vulnerable to environmental changes and that their resilience is reduced. In turn, there is clear evidence that marine reserves enhance resilience of ecosystems to climatic impacts (Micheli et al., 2012).

As determined by Philippart et al. (2011), a better understanding of potential climate change impacts can be obtained by: (i) modeling scenarios at both regional and local levels; (ii) developing improved methods to quantify the uncertainty of climate change projections; (iii) constructing usable climate change indicators; and (iv) improving the interface between science and policy formulation in terms of risk assessment. These factors are essential to formulate and inform better adaptive strategies to address the consequences of climate change.

\section{GRAND CHALLENGE 4: ASSESSING MARINE ECOSYSTEMS HEALTH IN AN INTEGRATIVE WAY}

Assessing the status of the oceans requires tools that allow us to define marine health across different marine habitats. Such tools have been developed in recent years, including ecological indicators to be applied to different ecosystem components (Birk et al., 2012; Halpern et al., 2012). One of the current challenges is to clearly understand what good status or good health is/means in marine systems and how we know when it has been attained (Borja et al., 2013a; Tett et al., 2013). This way, integrating knowledge across different ecosystem components and linking physical, chemical and biological aspects when assessing the status of marine systems is crucial for accurate evaluations (Borja et al., 2009, 2011).

However, one of the most critical issues when assessing the health status of marine ecosystems relates to the setting of adequate reference conditions and/or environmental targets to which monitoring data should be compared (Borja et al., 2012). These targets should be set taking the ecological characteristics of the studied ecosystems into account. 


\section{GRAND CHALLENGE 5: DELIVERING ECOSYSTEM SERVICES BY CONSERVING AND PROTECTING OUR SEAS}

Marine ecosystems provide numerous goods and services (Barbier et al., 2012), such as biogeochemical services (e.g., carbon sequestration), nutrient cycling, coastal protection (e.g., provided by coral reefs or phanerogams), food provision (e.g., fisheries), and grounds for tourism, etc. (Costanza et al., 1997). Despite the important role of such goods and services and albeit quickly attracting more attention, their study and their associated monetary value (often demanded to support conservation efforts) is still limited, particularly for the high seas and deep water habitats (Beaumont et al., 2007; Barbier et al., 2011; Braat and de Groot, 2012; Van den Belt and Costanza, 2012; Liquete et al., 2013; Thurber et al., 2013). Furthermore, recent debates have raised the question whether all ecosystem services can or should be quantified in monetary terms, when the public finds such values difficult to relate to.

It has been suggested that ecosystem services of high value critically depend on biodiversity (EASAC, 2009). As biodiversity loss is accelerating, maintaining biodiversity and healthy ecosystem services should be a priority when investigating, conserving and managing marine systems.

In marine management, Marine Protected Areas (MPAs) are an important tool for conserving and protecting biodiversity, by enhancing ecosystem resilience and adaptive capacity (Roberts et al., 2003; García-Charton et al., 2008). They allow for the mitigation of anthropogenic factors, such as overfishing or habitat destruction within their boundaries, by means of management or prohibition (Roberts et al., 2001; Mumby et al., 2006). Not only MPAs, but also the protection of near-natural ecosystems are very good strategies for managing climate change-related stressors and preserving biodiversity (Heller and Zavaleta, 2009).

Additional important issues in marine protection include the reduction of habitat fragmentation (Didham, 2010; Didham et al., 2012), determining the vulnerability of threatened species and habitats (Le Quesne and Jennings, 2012), and the study of connectivity between habitats and species distribution, which is a critical factor in maintaining habitat quality (Berglund et al., 2012).

\section{GRAND CHALLENGE 6: RECOVERING ECOSYSTEM STRUCTURE AND FUNCTIONING THROUGH RESTORATION}

Most estuarine, coastal and offshore waters worldwide have experienced significant degradation throughout the past three centuries (Lotze, 2010) and investments in marine protection have not been totally effective. Hence, ecological restoration is becoming an increasingly important tool to manage, conserve, and repair damaged ecosystems, as stated by Hobbs (2007).

Measuring effectiveness of restoration at habitat, community, or ecosystem level is not easy, and requires a focus on restoration of processes and functionality, rather than studying the recovery of particular species (Verdonschot et al., 2013). Thus, according to Borja et al. (2013c), restoration efforts should rely on what is known from theoretical and empirical ecological research on how communities and ecosystems recover in structure and function through time. Hence, studies on dispersal, colonization dynamics, patch dynamics, successional stages, metapopulations theory, etc., are needed for a deeper knowledge of recovery processes (Borja et al., 2010). This research will provide evidences to enhance restoration success of complex systems (Verdonschot et al., 2013).

\section{GRAND CHALLENGE 7: MANAGING THE SEAS USING THE ECOSYSTEM APPROACH AND SPATIAL PLANNING}

The management of marine systems, including the assessment of their overall health status, is increasingly carried out by applying ecosystem-based approaches (Borja et al., 2008). After all, the protection and conservation of marine ecosystems, together with the sustainable use of the services they provide, are of fundamental importance to the maintenance of global marine health (Tett et al., 2013). The goal of ecosystem-based management is to maintain an ecosystem in healthy, productive, and resilient conditions so that it can provide the services needed for the well-being of society (YáñezArancibia et al., 2013). The guiding principles for ecosystem-based management are founded on the idea that ocean and coastal resources should be managed to reflect the relationships among all ecosystem components, including humans, as well as the resulting socioeconomic impacts (YáñezArancibia et al., 2013).

In addition to the need for better management tools, the increasing anthropogenic impacts on marine waters (e.g., fisheries, aquaculture, shipping, renewable energies, recreation, mining, etc.) has promoted the discussion on how to manage and to conserve marine resources sustainably (Collie et al., 2013). Marine Spatial Planning, as defined by Ehler and Douvere (2009), is a management tool that attempts to balance conservation efforts with increasing demands on marine resources, which, together with the ecosystem-based approach, relies on a multidisciplinary approach integrating sociological, economic and ecological components (Qiu and Jones, 2013; Stelzenmüller et al., 2013).

\section{GRAND CHALLENGE 8: MODELING ECOSYSTEMS FOR BETTER MANAGEMENT}

The specificities of oceans when compared with terrestrial systems (see Norse and Crowder, 2005), and the increasingly complex approaches to investigate ecosystems at an integrative level requires the use of computer models (e.g., hydrodynamic, habitat suitability models, ecosystem models, etc.) for a better understanding of the processes, functioning and interrelationships among ecosystem components (Fulton et al., 2004). As a result, the use of species, ecological niche, habitat and ecosystem models has dramatically increased in recent years (Elith and Graham, 2009; Ready et al., 2010).

To guide conservation actions more effectively, the use of species distribution models has been recommended (Guisan et al., 2013), for example for studies on biological invasions, the identification of critical habitats, etc.

\section{CONCLUSION}

To adequately address the abovementioned grand challenges in Marine Ecosystem Ecology, effective long-term monitoring of populations and communities is required to understand marine ecosystem functioning and its responses 
to environmental and anthropogenic pressures (Stein and Cadien, 2009). However, monitoring programs often neglect important sources of error (e.g., the inability of investigators to detect all individuals or all species in a surveyed area) and thus can lead to biased estimates, spurious conclusions and false management actions (Katsanevakis et al., 2012). One of the newest ways to get reliable, verifiable, efficient and cost-effective monitoring of biodiversity is metabarcoding (Bourlat et al., 2013; Ji et al., 2013).

In addition to the acquisition of information on a regular basis, complete maps of habitats, ecosystem services, etc., are needed for a better understanding of spatial ecology and marine management (Brown et al., 2011). All this information requires data integration of the different ecosystem components in order to understand large-scale patterns and long-term changes (Stocks et al., 2009; Vandepitte et al., 2010).

Finally, the movement toward open access to scientific data and publications provides greater access to datasets and current research, which has the potential to result in better spatial and temporal analyses, by using existing information in a much more effective way through Information and Communication Technologies (i.e., e-Science). Make data open, accessible online in a standard format available for aggregation, integration, analysis and modeling, is a crucial step to boost the development of marine ecosystem ecology, to address the above highlighted challenges, and to move toward the frontiers of marine science (see Baird et al., 2011). Therefore, Frontiers in Marine Ecosystem Ecology promotes open access to data and information to enhance collaborations, whilst discussing hot marine topics and addressing the grand challenges described here.

\section{ACKNOWLEDGMENTS}

This manuscript writing has been partially supported by DEVOTES (DEVelopment Of innovative Tools for understanding marine biodiversity and assessing good Environmental Status) project, funded by the European Union under the 7 th Framework Programme, "The Ocean of Tomorrow" Theme (grant agreement no. 308392), www.devotes-project.eu.
Naiara Rodríguez-Ezpeleta and María C. Uyarra (AZTI-Tecnalia), and Alberto Basset (Associate Editor of Frontiers of Marine Ecosystem Ecology) have provided interesting comments to the manuscript. This paper is contribution number 659 from AZTI-Tecnalia (Marine Research Division).

\section{REFERENCES}

Baird, D. J., Baker, C. J. O., Brua, R. B., Hajibabaei, M., McNicol, K., Pascoe, T. J., et al. (2011). Toward a knowledge infrastructure for traits-based ecological risk assessment. Integr. Environ. Assess. Manag. 7, 209-215. doi: 10.1002/ieam.129

Ban, N. C., Alidina, H. M., and Ardron, J. A. (2010). Cumulative impact mapping: Advances, relevance and limitations to marine management and conservation, using Canada's Pacific waters as a case study. Mar. Policy 34, 876-886. doi: 10.1016/j.marpol.2010.01.010

Barbier, E. B., Hacker, S. D., Koch, E. W., Stier, A., and Silliman, B. (2012). "Estuarine and coastal ecosystems and their services. Chapter 6," in Ecological Economics of Estuaries and Coasts. Treatise on Estuarine and Coastal Science, Vol. 12, eds M. van den Belt and R. Costanza (Series eds E. Wolanski and D. McLusky), (Waltham, MA: Academic Press), 109-127.

Barbier, E. B., Hacker, S. D., Kennedy, C., Koch, E. W., Stier, A. C., and Silliman, B. R. (2011). The value of estuarine and coastal ecosystem services. Ecol. Monogr. 81, 169-193. doi: 10.1890/10-1510.1

Beaumont, N. J., Austen, M. C., Atkins, J. P., Burdon, D., Degraer, S., Dentinho, T. P., et al. (2007). Identification, definition and quantification of goods and services provided by marine biodiversity: Implications for the ecosystem approach. Mar. Pollut. Bull. 54, 253-265. doi: 10.1016/j.marpolbul.2006.12.003

Benedetti-Cecchi, L. (2005). Unanticipated impacts of spatial variance of biodiversity on plant productivity. Ecol. Lett. 8, 791-799. doi: 10.1111/j.14610248.2005.00780.x

Berglund, M., Nilsson Jacobi, M., and Jonsson, P. R. (2012). Optimal selection of marine protected areas based on connectivity and habitat quality. Ecol. Modelling 240, 105-112. doi: 10.1016/j.ecolmodel.2012.04.011

Birk, S., Bonne, W., Borja, A., Brucet, S., Courrat, A. Poikane, S., et al. (2012). Three hundred ways to assess Europe's surface waters: an almost complete overview of biological methods to implement the Water Framework Directive. Ecol. Indic. 18, 31-41. doi: 10.1016/j.ecolind.2011.10.009

Borja, A., Bricker, S. B., Dauer, D. M., Demetriades, N. T., Ferreira, J. G., Forbes, A. T., et al. (2008). Overview of integrative tools and methods in assessing ecological integrity in estuarine and coastal systems worldwide. Mar. Pollut. Bull. 56, 1519-1537. doi: 10.1016/j.marpolbul.2008. 07.005

Borja, Á., Dauer, D., Elliott, M., and Simenstad, C. (2010). Medium- and long-term recovery of estuarine and coastal ecosystems: patterns, rates and restoration effectiveness. Estuaries Coasts 33, 1249-1260. doi: 10.1007/s12237-010-9347-5
Borja, Á., Dauer, D. M., and Grémare, A. (2012). The importance of setting targets and reference conditions in assessing marine ecosystem quality. Ecol. Indic. 12, 1-7. doi: 10.1016/j.ecolind.2011. 06.018

Borja, A., Elliott, M., Andersen, J. H., Cardoso, A. C., Carstensen, J., Ferreira, J. G., et al. (2013a) Good Environmental Status of marine ecosystems: What is it and how do we know when we have attained it? Mar. Pollut. Bull. 76, 16-27. doi: 10.1016/j.marpolbul.2013.08.042

Borja, Á., Fontán, A., and Muxika, I. (2013b). Interactions between climatic variables and human pressures upon a macroalgae population: Implications for management. Ocean Coast. Manag. 76, 85-95. doi: 10.1016/j.ocecoaman.2013.02.023

Borja, Á., Galparsoro, I., Irigoien, X., Iriondo, A., Menchaca, I., Muxika, I., et al. (2011) Implementation of the european marine strategy framework directive: a methodological approach for the assessment of environmental status, from the Basque Country (Bay of Biscay). Mar. Pollut. Bull. 62, 889-904. doi: 10.1016/j.marpolbul.2011.03.031

Borja, A., Marques, J.-C., Olabarria, C., and Quintino, V. (2013c). Marine research in the Iberian Peninsula: a pledge for better times after an economic crisis. J. Sea Res. 83, 1-8. doi: 10.1016/j.seares.2013.07.004

Borja, A., Ranasinghe, A., and Weisberg, S. B. (2009). Assessing ecological integrity in marine waters, using multiple indices and ecosystem components: challenges for the future. Mar. Pollut. Bull. 59, 1-4. doi: 10.1016/j.marpolbul.2008.11.006

Bourlat, S. J., Borja, A., Gilbert, J., Taylor, M. I., Davies, N., Weisberg, S. B., et al. (2013). Genomics in marine monitoring: new opportunities for assessing marine health status. Mar. Pollut. Bull. 74, 19-31. doi: 10.1016/j.marpolbul. 2013.05.042

Braat, L. C., and de Groot, R. (2012). The ecosystem services agenda: bridging the worlds of natural science and economics, conservation and development, and public and private policy. Ecosyst. Serv. 1, 4-15. doi: 10.1016/j.ecoser.2012.07.011

Brown, C. J., Smith, S. J., Lawton, P., and Anderson, J. T. (2011). Benthic habitat mapping: a review of progress towards improved understanding of the spatial ecology of the seafloor using acoustic techniques. Estuar. Coast. Shelf Sci. 92, 502-520. doi: 10.1016/j.ecss.2011.02.007

Collie, J. S., Adamowicz, W. L., Beck, M. W., Craig, B., Essington, T. E., Fluharty, D., et al. (2013). Marine spatial planning in practice. Estuar. Coast. Shelf Sci. 117, 1-11. doi: 10.1016/j.ecss.2012.11.010

Costanza, R., D’Arge, R., de Groot, R., Farber, S., Grasso, M., Hannon, B., et al. (1997). The value of the world's ecosystem services and natural capital. Nature 387, 253-260.

Didham, R. K. (2010). "Ecological consequences of habitat fragmentation," in Encyclopedia of Life Sciences (ELS), ed R. Jansson (Chichester: John Wiley \& Sons, Ltd.). doi: 10.1002/9780470015902.a0021904

Didham, R. K., Kapos, V., and Ewers, R. M. (2012). Rethinking the conceptual foundations of habitat fragmentation research. Oikos 121, 161-170. doi: 10.1111/j.1600-0706.2011.20273.x 
EASAC. (2009). Ecosystem services and biodiversity in Europe. EASAC Policy Rep. 9, 79. Available online at: http://www.sazu.si/files/file-137.pdf

Edeline, E., Lacroix, G., Delire, C., Poulet, N., and Legendre, S. (2013). Ecological emergence of thermal clines in body size. Glob. Chang. Biol. 19, 3062-3068. doi: 10.1111/gcb.12299

Ehler, C., and Douvere, F. (2009). Marine Spatial Planning: a step-by-step approach toward ecosystem-based management. Intergovernmental Oceanographic Commission and Man and the Biosphere Programme. IOC Manual and Guides No. 53, ICAM Dossier No. 6. Paris: UNESCO.

Elith, J., and Graham, C. H. (2009). Do they? How do they? Why do they differ? On finding reasons for differing performances of species distribution models. Ecography 32, 66-77. doi: 10.1111/j.16000587.2008.05505.x

Elliott, M., Burdon, D., Hemingway, K. L., and Apitz, S. E. (2007). Estuarine, coastal and marine ecosystem restoration: confusing management and science - A revision of concepts. Estuar. Coast. Shelf Sci. 74, 349-366. doi: 10.1016/j.ecss.2007.05.034

Folke, C., Carpenter, S., Walker, B., Scheffer, M., Elmqvist, T., Gunderson, L., et al. (2004). Regime shifts, resilience, and biodiversity in ecosystem management. Аnnu. Rev. Ecol. Evol. Syst. 35, 557-581. doi: 10.1146/annurev.ecolsys.35.021103.105711

Fulton, E. A., Smith, A. D. M., and Johnson, C. R. (2004). Biogeochemical marine ecosystem models I: IGBEM - a model of marine bay ecosystems. Ecol. Modelling 174, 267-307. doi: 10.1016/j.ecolmodel.2003.09.027

García-Charton, J. A., Pérez-Ruzafa, A., Marcos, C., Claudet, J., Badalamenti, F., Benedetti-Cecchi, L., et al. (2008). Effectiveness of european atlantomediterranean MPAs: do they accomplish the expected effects on populations, communities and ecosystems? J. Nat. Conserv. 16, 193-221. doi: 10.1016/j.jnc.2008.09.007

Guisan, A., Tingley, R., Baumgartner, J. B., Naujokaitis-Lewis, I., Sutcliffe, P. R., Tulloch, A. I., et al. (2013). Predicting species distributions for conservation decisions. Ecol. Lett. 16, 1424-1435. doi: 10.1111/ele.12189

Halpern, B. S., Longo, C., Hardy, D., McLeod, K. L., Samhouri, J. F., Katona, S. K., et al. (2012). An index to assess the health and benefits of the global ocean. Nature 488, 615-620. doi: 10.1038/nature11397

Halpern, B. S., Walbridge, S., Selkoe, K. A., Kappel, C. V., Micheli, F., D’Agrosa, C., et al. (2008). A global map of human impact on marine ecosystems. Science 319, 948-952. doi: 10.1126/science. 1149345

Heller, N. E., and Zavaleta, E. S. (2009). Biodiversity management in the face of climate change: a review of 22 years of recommendations. Biol. Conserv. $142,14-32$.

Hobbs, R. J. (2007). Setting effective and realistic restoration goals: key directions for research. Restor. Ecol. 15, 354-357. doi: 10.1111/j.1526100X.2007.00225. $\mathrm{x}$

Hooper, D. U., Adair, E. C., Cardinale, B. C., Byrnes, J. E. K., Hungate, B. A., Matulich, K. L., et al. (2012). A global synthesis reveals biodiversity loss as a major driver of ecosystem change. Nature 486, 105-108. doi: 10.1038/nature11118
Ji, Y., Ashton, L., Pedley, S. M., Edwards, D. P., Tang, Y., Nakamura, A., et al. (2013). Reliable, verifiable and efficient monitoring of biodiversity via metabarcoding. Ecol. Lett. 16, 1245-1257. doi: 10.1111/ele.12162

Katsanevakis, S., Weber, A., Pipitone, C., Leopold, M., Cronin, M., Scheidat, M., et al. (2012). Monitoring marine populations and communities: methods dealing with imperfect detectability. Aquat. Biol. 16, 31-52. doi: 10.3354/ab00426

Le Quesne, W. J. F., and Jennings, S. (2012). Predicting species vulnerability with minimal data to support rapid risk assessment of fishing impacts on biodiversity. J. Appl. Ecol. 49, 20-28. doi: 10.1111/j.1365-2664.2011.02087.x

Liquete, C., Piroddi, C., Drakou, E. G., Gurney, L., Katsanevakis, S., Charef, A., et al. (2013). Current status and future prospects for the assessment of marine and coastal ecosystem services: a systematic review. PLoS ONE 8:e67737. doi: 10.1371/journal.pone.0067737

Livingston, P. A., Aydin, K., Boldt, J. L., Hollowed, A. B., and Napp, J. M. (2011). "Alaska marine fisheries management: advances and linkages to ecosystem research. Chapter 3," in Ecosystembased Management for Marine Fisheries: an Evolving Perspective, eds A. Belgrano and C. W. Fowler (Cambridge University Press), 113-152. doi: 10.1017/CBO9780511973956.006

Lotze, H. K. (2010). Historical reconstruction of human-induced changes in U.S. estuaries. Oceanogr. Mar. Biol. Ann. Rev. 48, 267-338. doi: 10.1201/EBK1439821169-c5

Micheli, F., Halpern, B. S., Walbridge, S., Ciriaco, S., Ferretti, F., Fraschetti, S., et al. (2013). Cumulative human impacts on mediterranean and black sea marine ecosystems: assessing current pressures and opportunities. PLoS ONE 8:e79889. doi: 10.1371/journal.pone.0079889

Micheli, F., Saenz-Arroyo, A., Greenley, A., Vazquez, L., Espinoza Montes, J. A., Rossetto, M., et al. (2012). Evidence that marine reserves enhance resilience to climatic impacts. PLOS ONE 7:e40832. doi: 10.1371/journal.pone.0040832

Mumby, P. J., Dahlgren, C. P., Harborne, A. R., Kappel, C. V., Micheli, F., Brumbaugh, D. R., et al. (2006). Fishing, trophic cascades, and the process of grazing on coral reefs. Science 311, 98-101. doi: 10.1126/science.1121129

Munday, P. L., Warner, R. R., Monro, K., Pandolfi, J. M., and Marshall, D. J. (2013). Predicting evolutionary responses to climate change in the sea. Ecol. Lett. 16, 1488-1500. doi: 10.1111/ele.12185

Norse, E. A., and Crowder, L. B. (eds.). (2005). Marine Conservation Biology: The Science of Maintaining the Sea's Biodiversity. Washington, DC: Island Press.

Olenin, S., Elliott, M., Bysveen, I., Culverhouse, P. F., Daunys, D., Dubelaar, G. B. J., et al. (2011). Recommendations on methods for the detection and control of biological pollution in marine coastal waters. Mar. Pollut. Bull. 62, 2598-2604. doi: 10.1016/j.marpolbul.2011.08.011

Philippart, C. J. M., Anadón, R., Danovaro, R., Dippner, J. W., Drinkwater, K. F. Hawkins, S., et al. (2011). Impacts of climate change on European marine ecosystems: observations, expectations and indicators. J. Exp. Mar. Biol. Ecol. 400, 52-69. doi: 10.1016/j.jembe.2011.02.023
Poloczanska, E. S., Brown, C. J., Sydeman, W. J., Kiessling, W., Schoeman, D. S., Moore, P. J., et al. (2013). Global imprint of climate change on marine life. Nat. Clim. Chang. 3, 919-925. doi: 10.1038/nclimate 1958

Qiu, W., and Jones, P. J. S. (2013). The emerging policy landscape for marine spatial planning in Europe. Mar. Policy 39, 182-190. doi: 10.1016/j.marpol.2012.10.010

Ready, J., Kaschner, K., South, A. B., Eastwood, P. D., Rees, T., Rius, J., et al. (2010). Predicting the distributions of marine organisms at the global scale. Ecol. Modelling 221, 467-478. doi: 10.1016/j.ecolmodel.2009.10.025

Richardson, A. J., Brown, C. J., Brander, K., Bruno, J. F., Buckley, L., Burrows, M. T., et al. (2012) Climate change and marine life. Biol. Lett. 8, 907-909. doi: 10.1098/rsbl.2012.0530

Roberts, C. M., Andelman, S., Branch, G., Bustamante, R. H., Castilla, J. C., Dugan, J., et al. (2003). Ecological criteria for evaluating candidate sites for marine reserves. Ecol. Appl. 13, S199-S214. doi: 10.1890/10510761(2003)013[0199:ECFECS]2.0.CO;2

Roberts, C. M., Bohnsack, J. A., Gell, F., Hawkins, J. P., and Goodridge, R. (2001). Effects of marine reserves on adjacent fisheries. Science 294, 1920-1923. doi: 10.1126/science.294.55 48.1920

Rockström, J., Steffen, W., Noone, K., Persson, A., Chapin, I., Lambin, F. S., et al. (2009). Planetary boundaries:exploring the safe operating space for humanity. Ecol. Soc. 14, 32. Available online at: http://www.ecologyandsociety.org/vol14/iss2/ art32/

Sorte, C. J. B., Williams, S. L., and Carlton, J. T. (2010). Marine range shifts and species introductions: comparative spread rates and community impacts. Glob. Ecol. Biogeogr. 19, 303-316. doi: 10.1111/j.1466-8238.2009.00519.x

Stein, E. D., and Cadien, D. B. (2009). Ecosystem response to regulatory and management actions: the southern California experience in long-term monitoring. Mar. Pollut. Bull. 59, 91-100. doi: 10.1016/j.marpolbul.2009.02.025

Stelzenmüller, V., Lee, J., South, A., Foden, J., and Rogers, S. I. (2013). Practical tools to support marine spatial planning: a review and some prototype tools. Mar. Policy 38, 214-227. doi: 10.1016/j.marpol.2012.05.038

Stocker, T., Dahe, Q., and Plattner, G. K. E. (2013). Working Group I Contribution to the IPCC Fifth Assessment Report Climate Change 2013, The Physical Science Basis. Final draft underlying scientific-technical assessment IPCC, (Stockholm).

Stocks, K. I., Condit, C., Qian, X., Brewin, P. E., and Gupta, A. (2009). Bringing together an ocean of information: an extensible data integration framework for biological oceanography. Deep Sea Res. II Top. Stud. Oceanogr. 56, 1804-1811. doi: 10.1016/j.dsr2.2009.05.022

Tett, P., Gowen, R. J., Painting, S. J., Elliott, M., Forster, R., Mills, D. K., et al. (2013). Framework for understanding marine ecosystem health. Mar. Ecol. Prog. Ser. 494, 1-27. doi: 10.3354/meps10539

Thompson, R. M., Brose, U., Dunne, J. A., Hall, R. O. Jr., Hladyz, S., Kitching, R. L., et al. (2012) Food webs: reconciling the structure and function 
of biodiversity. Trends Ecol. Evol. 27, 689-697. doi: 10.1016/j.tree.2012.08.005

Thurber, A. R., Sweetman, A. K., Narayanaswamy, B. E., Jones, D. O. B., Ingels, J., and Hansman, R. L. (2013). Ecosystem function and services provided by the deep sea. Biogeosci. Discuss. 10, 18193-18240. doi: 10.5194/bgd-10-18193-2013

Tomimatsu, H., Sasaki, T., Kurokawa, H., Bridle, J. R., Fontaine, C., Kitano, J., et al. (2013). Sustaining ecosystem functions in a changing world: a call for an integrated approach. J. Appl. Ecol. 50, 1124-1130. doi: 10.1111/1365-2664. 12116

Van den Belt, M., and Costanza, R. (2012). "Ecological economics of estuaries and coasts," in Treatise on Estuarine and Coastal Science, Vol. 12, eds E. Wolanski and D. S. McLusky (Waltham, MA: Academic Press), 525.

Vandepitte, L., Vanhoorne, B., Kraberg, A., Anisimova, N., Antoniadou, C., Araújo, R., et al. (2010). Data integration for European marine biodiversity research: creating a database on benthos and plankton to study large-scale patterns and long-term changes. Hydrobiologia 644, 1-13. doi: 10.1007/s10750-0100108-z

Verdonschot, P. F. M., Spears, B. M., Feld, C. K., Brucet, S., Keizer-Vlek, H., Borja, A., et al. (2013). A comparative review of recovery processes in rivers, lakes, estuarine and coastal waters. Hydrobiologia 704, 453-474. doi: 10.1007/s10750012-1294-7

Vilà, M., Basnou, C., Pysek, P., Josefsson, M., Genovesi, P., Gollasch, S., et al. (2010). How well do we understand the impacts of alien species on ecosystem services? A pan-European, cross-taxa assessment. Front. Ecol. Environ. 8:135-144. doi: $10.1890 / 080083$

Yáñez-Arancibia, A., Day, J. W., and Reyes, E. (2013). Understanding the coastal ecosystem-based man- agement approach in the Gulf of Mexico. J. Coast. Res. 63, 243-261. doi: 10.2112/SI63-018.1

Received: 19 December 2013; accepted: 04 February 2014; published online: 12 February 2014.

Citation: Borja A (2014) Grand challenges in marine ecosystems ecology. Front. Mar. Sci. 1:1. doi: 10.3389/ fmars.2014.00001

This article was submitted to Marine Ecosystem Ecology, a section of the journal Frontiers in Marine Science.

Copyright (c) 2014 Borja. This is an open-access article distributed under the terms of the Creative Commons Attribution License (CC BY). The use, distribution or reproduction in other forums is permitted, provided the original author(s) or licensor are credited and that the original publication in this journal is cited, in accordance with accepted academic practice. No use, distribution or reproduction is permitted which does not comply with these terms. 